Arch Virol (1994) [Suppl] 9: 417-427

Virrology

(C) Springer-Verlag 1994

\title{
Molecular characterization of Borna virus RNAs
}

\author{
J. M. Pyper, L. Brown, and J. E. Clements \\ Division of Comparative Medicine, The Johns Hopkins University School of Medicine, \\ Baltimore, Maryland, U.S.A.
}

Summary. Borna disease virus is cell-associated in infected animals. Antibodies in animals are directed against BDV proteins of 38/39, 24, and $14.5 \mathrm{kD}$. cDNA clones that encode these proteins hybridize to five mRNAs of $10.5,3.6,2.1,1.4$, and $0.85 \mathrm{~kb}$. The $10.5,3.6,2.1$, and $0.85 \mathrm{~kb}$ RNAs are $3^{\prime}$ co-terminal; the $1.4 \mathrm{~kb}$ RNA is contained within the $10.5,3.6$, and $2.1 \mathrm{~kb}$ species but is not $3^{\prime}$ co-terminal. A negative strand $10 \mathrm{~kb}$ RNA is also present in infected cells. To determine which of the large $10 \mathrm{~kb}$ species represents the genomic RNA, strand-specific probes were used for Northern analyses of RNA from infectious particles isolated by Freon extraction of BDV-infected rat brain. RNA purified from these particles contained both positive and negative sense $10 \mathrm{~kb}$ species. Treatment of particles with RNaseA before isolation of RNA resulted in detection of only negative strand species, suggesting that $\mathrm{BDV}$ is a negative strand RNA virus. However, the genomic organization of BDV is unlike any known negative strand RNA virus.

\section{Introduction}

Borna disease is a rare but severe neurological disease that infects horses and sheep in parts of Germany and Switzerland. It was first described nearly a century ago in the town of Borna, Saxony [1]. In 1927 Zwick et al. [2] determined that a virus caused the disease, but despite years of work, the viral agent has not yet been classified. Although Borna disease is rare, the immunopathological nature of the disease and the wide range of vertebrates that can be infected (avians to primates) make it an interesting disease model. Further, the ability of the virus to replicate in neuronal cells in both the central and peripheral nervous systems make it an attractive model for central nervous system (CNS) disease. In natural infections Borna disease has only been identified in horses and sheep, but similar behavioral diseases in humans have been linked to the agent by results of serologic studies [3, 4]. 


\section{Borna disease}

Infected animals exhibit severe neurological symptoms, such as ataxia, excitation, abnormal posture, lethargy, and blindness. Examination of the brains of infected animals shows encephalomyelitis, with the most severe lesions located in the cerebral cortex and the hippocampus. Infectivity can be transmitted to uninfected animals by intracranial inoculation of brain homogenate from an infected animal. Thus far it has been impossible to isolate cell-free infectious virus from infected animals (or from cells infected in culture); all infectivity is cell-associated. This has hindered efforts to classify the virus.

The dependence of the virus on infection of neurons has been shown by experiments in which virus is inoculated into the footpad of a rat. CNS disease results after transport through nerve processes. However, viral transport to the CNS can be blocked if the sciatic nerve is transected prior to or soon after inoculation [5]. Transmission of infection has also been demonstrated by inoculating the nasal epithelium [6, 7]. In contrast, intravenous inoculation with the same inoculum usually fails to cause disease [5]. These results have demonstrated that the most efficient route of infection in the host is via the nerves.

\section{Immunopathology of Borna disease}

The outcome of infection with the etiologic agent of Borna disease, herein called Borna disease virus (BDV) for convenience, depends on the age of the animal at the time of inoculation. Adult rats inoculated with BDV develop disease characterized by an initial phase of frenzied aggressive behavior and followed by a chronic passive phase. There is a high titer of virus in the brains of these acutely infected animals. In contrast, neonatal rats do not develop clinical signs of disease even though there are high titers of BDV in their brains. This persistent tolerant infection (PTI) is accompanied by subtle changes in behavior [8]. The age-dependent difference in response to BDV has been shown to be due to the state of the host's immune system [9, 10]. Neither adult animals immunosuppressed with cyclosporine $A$ [11] nor athymic adult rats [12] develop the clinical disease seen in immunocompetent adults. Characteristic lesions in the brains of animals with Borna disease are immunopathological in nature and are caused by CD4+ T cells [13]. Immunocompetent animals respond to infection by producing antibodies specific to BDV, but these antibodies are not protective and do not neutralize infectivity either in vivo or in vitro. However, these antibodies have been useful both diagnostically and for characterization of the prominent BDV proteins produced during infection.

$\mathrm{BDV}$ is similar to lymphocytic choriomeningitis (LCM) virus in that both viruses can establish a persistent tolerant infection (PTI) in neo- 
natal animals. However, BDV persists only in neurons and astrocytes [14] whereas the LCM virus persists in many cell types (neurons, meningeal and choroid plexus cells, lymphocytes, macrophages, hepatocytes, etc.) [15]. Additionally, LCM-PTI mice can be cured of their infection by adoptive immunization with activated, immunologically specific CTL from adult mice [16] whereas BDV-PTI rats have not been cured using a similar strategy.

\section{Borna disease virus}

\section{Culture of $B D V$}

Although cell-free virus cannot be isolated from infected animals, a homogenate from infected brain is infectious for other animals and for some cells in culture. Cultured fetal rabbit glial cells (FRGs) can be directly infected by these homogenates and FRGs have been used to titrate virus in brain and other organs. However, these cells do not produce significant quantities of virus because of their limited growth capacity in culture. The MDCK cell line cannot be directly infected using brain homogenates, but a persistently infected MDCK line can be established after cocultivation with infected FRG cells. Clonal cell lines can then be isolated which are uniformly infected. No cell-free virus is produced in either the BDV-infected FRGs or in persistently infected MDCKs.

\section{Physical characteristics of $B D V$}

Homogenates from either PTI rat brains or persistently infected cell lines have been used to assess physical characteristics of BDV. From early filtration experiments the size of the particle has been estimated to be approximately $85-125 \mathrm{~nm}[17,18]$. Density gradient centrifugation concentrated infectivity at $\sim 1.2 \mathrm{~g} / \mathrm{ml}$ (ranging from 1.18 to $1.22 \mathrm{~g} / \mathrm{ml}$ ) $[19,20]$.

BDV-specific proteins have been characterized using immune sera. From both Western analyses and immunoprecipitations of labeled proteins from infected MDCK cells, prominent BDV-specific proteins of $38 / 39,24$, and $14.5 \mathrm{kD}$ can be detected [21-23]. The large amounts of the $38 / 39$ and $24 \mathrm{kD}$ proteins made it possible to purify enough material to obtain limited amino acid sequence from proteolytic fragments.

\section{Molecular characterization of BDV}

Several laboratories used molecular techniques to extend the characterization of BDV. Because it was not known whether BDV was an RNA or DNA virus, initial approaches utilized cDNA cloning of mRNA from infected cells using subtractive libraries. In our laboratory, an expression 


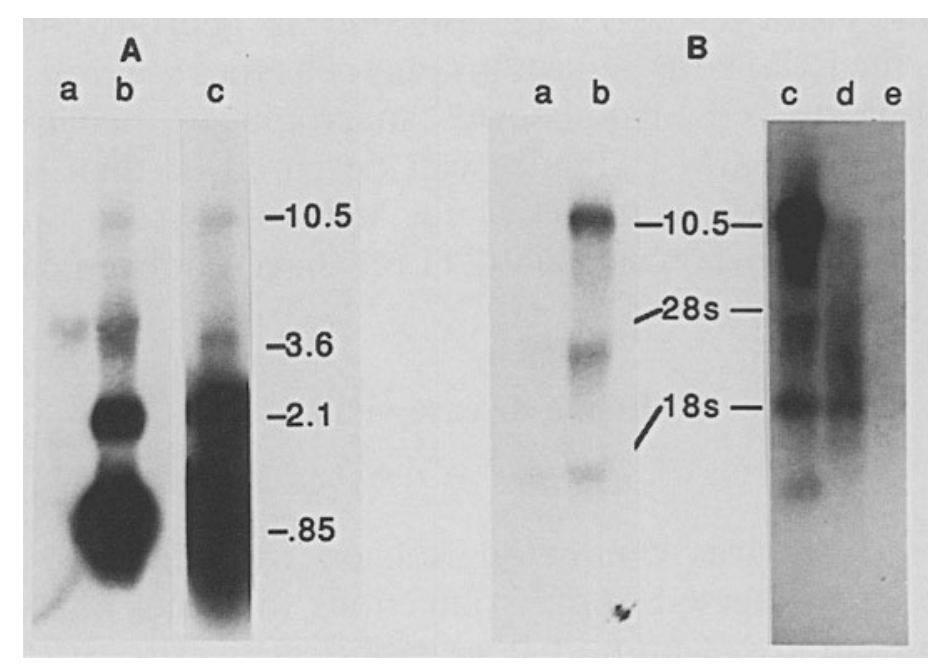

Fig. 1. Northern analysis determination of polarity of BDV transcripts. A Detection of mRNAs using a BDV anti-sense riboprobe generated from clone B8. a 7.5 $\mu$ RNA from uninfected rat brain; $b 7.5 \mu \mathrm{g}$ RNA from BDV-infected rat brain; $c 2.0 \mu \mathrm{g}$ poly A + RNA from BDV-infected rat brain. B Detection of negative-sense transcripts using a BDV sense riboprobe generated from clone B8. a $7.5 \mu \mathrm{g}$ RNA from uninfected rat brain; $b 7.5 \mu \mathrm{g}$ RNA from BDV-infected rat brain; $c 5 \mu \mathrm{g}$ of total RNA from BDVinfected rat brain; $d 3 \mu \mathrm{g}$ of RNA from oligo(dT) column wash; $e 3 \mu \mathrm{g}$ of polyA+ RNA

library was screened using monoclonal antibodies to the $38 / 39 \mathrm{kD}$ proteins $[24,25]$. Other laboratories screened their libraries using subtractive probes $[26,27]$ or oligonucleotide probes based on the amino acid sequence of the proteolytic fragments of purified proteins [23]. The three techniques led to the isolation of cDNA clones encoding the $24 \mathrm{kD}$ protein.

\section{Analysis of RNA species using probes specific for the $24 \mathrm{kD}$ ORF}

The initial molecular clone characterized was a $700 \mathrm{bp}$ clone (B8) isolated from the MDCK subtractive library [24, 25]. Radiolabeled probes made from this clone hybridized only to RNA from infected cells and not to DNA. This demonstrated that BDV was an RNA virus; similar results were reported by Lipkin et al. [27]. Using strand-specific probes and sequence information (see below), it was shown that there were four polyadenylated transcripts of positive orientation $(10.5,3.6,2.1$, and $0.85 \mathrm{~kb}$ ) and three of negative orientation (10.0, 3.5, and 1.7 kb) (Fig. 1). The data suggested that the mRNAs could be described as a $3^{\prime}$ coterminal nested set similar to the organization seen in the coronavirus superfamily [25]. 


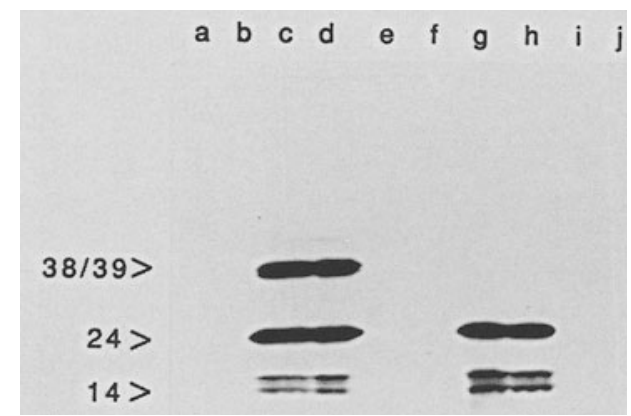

Fig. 2. Identification of BDV-specific proteins encoded by the B8 clone. Proteins were in vitro translated either from polyA + RNA isolated from rat brain or from in vitro transcribed RNA and then immunoprecipitated with anti-BDV sera from rat or rabbit. In vitro translations contained: polyA + RNA from uninfected rat brain ( $a$ and $b$ ); polyA + RNA from BDV-infected rat brain $(c$ and $d)$; in vitro transcribed anti-sense RNA from clone B8 ( $e$ and $f$ ); in vitro transcribed sense RNA from clone B8 ( $g$ and $h$ ); no RNA $(i$ and $j$ ). Proteins were immunoprecipitated using polyclonal anti-BDV sera from rat $(a, c, e, g$, and $i)$ or rabbit $(b, d, f, h$, and $j)$

Analysis of the nucleotide sequence of the $\mathrm{B} 8$ clone predicted that it would encode two proteins $[24,25,28]$. The predicted amino acid sequence contained peptide sequences previously determined for the p24 proteolytic fragments. In vitro transcription and translation of B8 followed by immunoprecipitation with rat sera from an infected animal showed that $24,14.5$, and $13 \mathrm{kD}$ proteins were encoded by B8 (Fig. 2).

\section{$c D N A s$ encoding the $38 \mathrm{kD}$ protein}

In this laboratory a second subtractive library was also generated using BDV-infected rat brain as the source of mRNA for cDNA cloning [28]. This library was screened using oligonucleotides derived from the $5^{\prime}$ end of $\mathrm{B} 8$ as probes. One clone, E20/1, contained most of the B8 sequence but also extended $5^{\prime}$ of B8 by $140 \mathrm{nt}$. Sequence analysis of this clone showed that the additional $140 \mathrm{nt}$ contained a sequence corresponding to the amino acid sequence from a proteolytic fragment of the $38 \mathrm{kD}$ protein.

Clones encoding sequences $5^{\prime}$ of E20/1 were obtained by applying the RACE technique [29] to gel-purified primer extension products [28]. A cDNA clone, pcDNA2.1, encodes the entire $38 \mathrm{kD}$ protein. The predicted amino acid sequence of this clone contained eight peptide sequences previously identified from proteolytic fragments of the $38 \mathrm{kD}$ protein, including those previously identified in E20/1. This was confirmed using in vitro transcription and translation, followed by immu- 


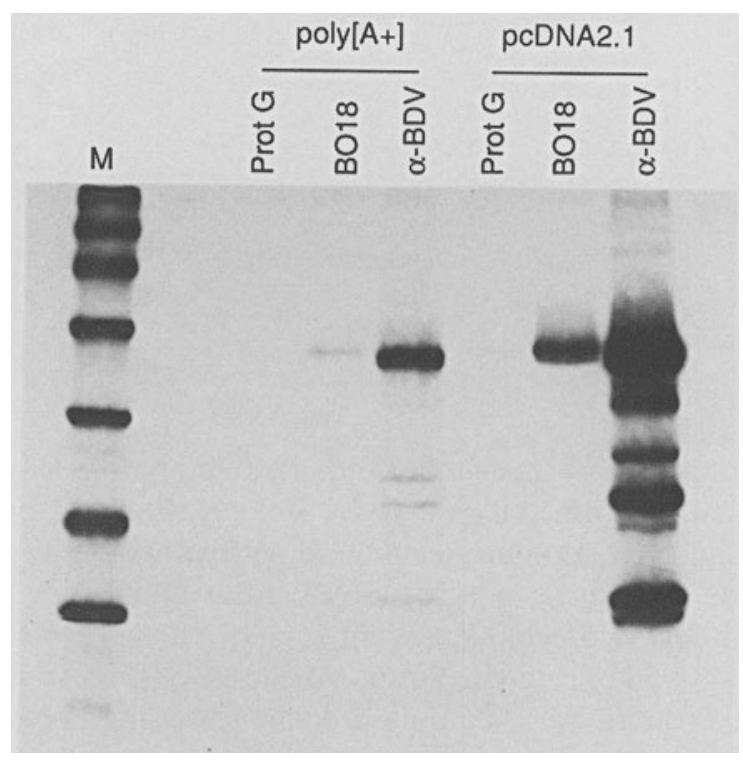

Fig. 3. Immunoprecipitation of the in vitro translated $38 \mathrm{kD}$ BDV-specific protein. Proteins were in vitro translated using poly $\mathrm{A}+$ RNA from rat brain ( $\operatorname{poly}\left[A^{+}\right]$) or RNA in vitro transcribed from pcDNA2.1 in the sense orientation ( $p c D N A 2.1)$. Proteins were immunoprecipitated with Protein G Sepharose only (Prot G); BO18 (monoclonal antibody to the $38 \mathrm{kD}$ protein) and Protein G Sepharose (BO18); or polyclonal anti-BDV rabbit sera and Protein G Sepharose $(\alpha-B D V)$

noprecipitation using a monoclonal antibody specific for the $38 \mathrm{kD}$ protein (Fig. 3).

Comparison of $m R N A$ s detected using probes specific for the $24 \mathrm{kD}$ or $38 \mathrm{kD}$ ORFs

Earlier analyses of RNA species used oligonucleotide probes derived from clone $\mathrm{B} 8$, which encodes the 14 and $24 \mathrm{kD}$ proteins. We extended this analysis using oligonucleotide probes specific for the $38 \mathrm{kD}$ open reading frame (ORF). Using a Northern transfer of a $30 \mathrm{~cm}$ formaldehydeagarose gel to improve resolution of RNA species, we were able to detect an additional mRNA species of $1.4 \mathrm{~kb}$, which was specifically hybridized by probes derived from the $38 \mathrm{kD}$ ORF. Interestingly, these probes failed to hybridize to the $0.85 \mathrm{~kb}$ mRNA (Fig. 4A). These results suggest that the organization of the BDV mRNAs is more complex than originally postulated and that they cannot be accurately and simply described as a nested set of $3^{\prime}$ coterminal transcripts. One possible arrangement of mRNAs is shown schematically in Fig. 4B. It remains to be seen whether additional mRNAs will be detected when probes specific to other protein coding regions are obtained. 


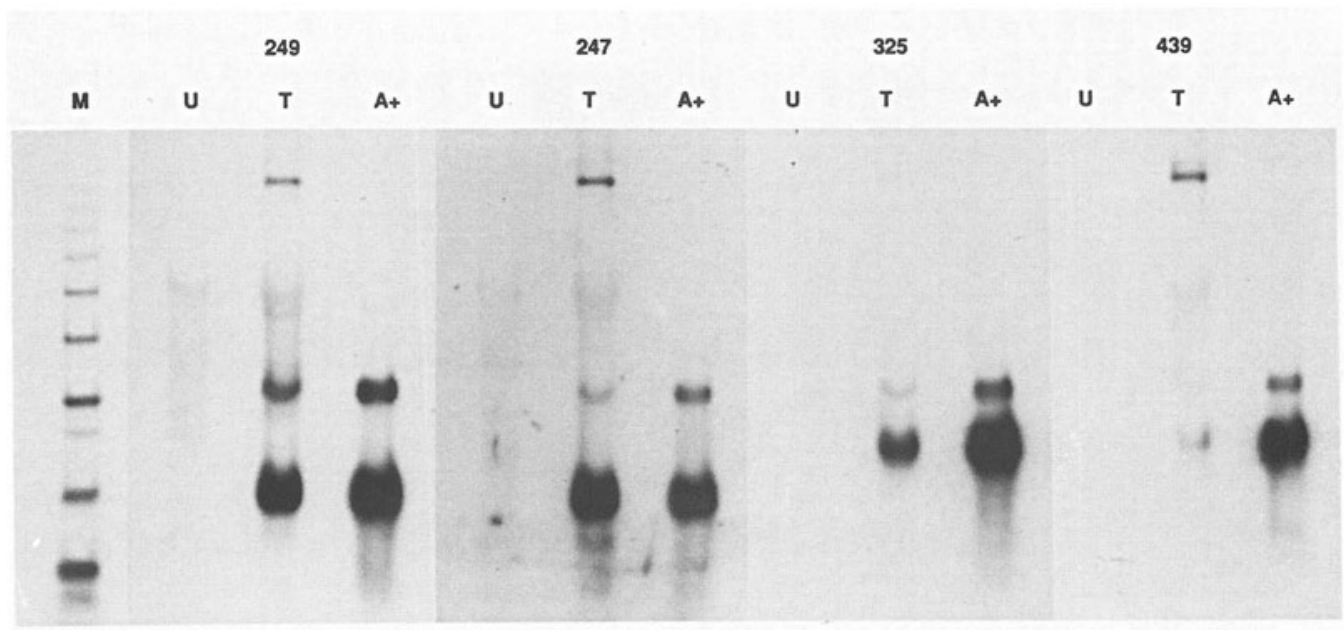

mRNA Transcripts for the BDV Structural Genes

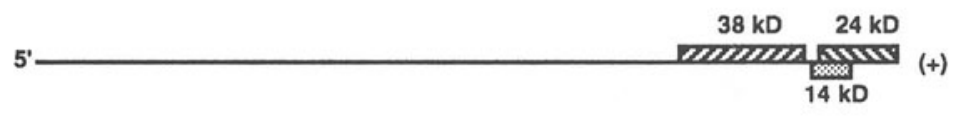

5 '

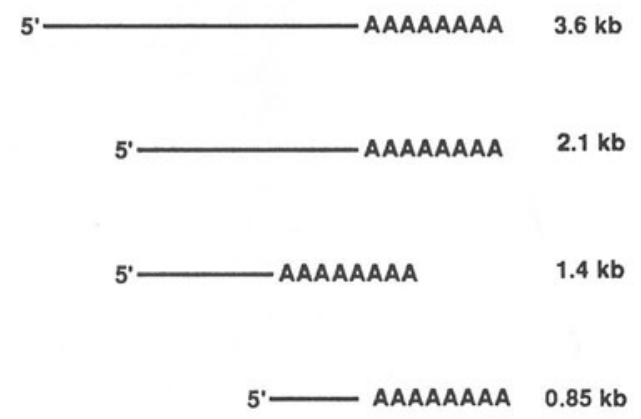

Fig. 4. BDV mRNAs. A Northern analysis of BDV RNAs. RNA samples were electropheresed in a $30 \mathrm{~cm}$ agarose-formaldehyde gel and transferred to nylon. The blot was sequentially probed with oligonucleotides located within the $24 \mathrm{kD}$ ORF ( 249 and 247 ) or within the $38 \mathrm{kD}$ ORF (325 and 439). $U 10 \mu \mathrm{g}$ total RNA from uninfected rat brain; $T 10 \mu \mathrm{g}$ total RNA from BDV-infected rat brain; $A+0.5 \mu \mathrm{g}$ polyA+ RNA from BDV-infected rat brain. B mRNA transcripts for the structural genes of BDV. The top line shows the locations of the three ORFs for the structural proteins relative to the full-length BDV sense strand RNA. Below are shown the polyadenylated mRNA species which have been identified 

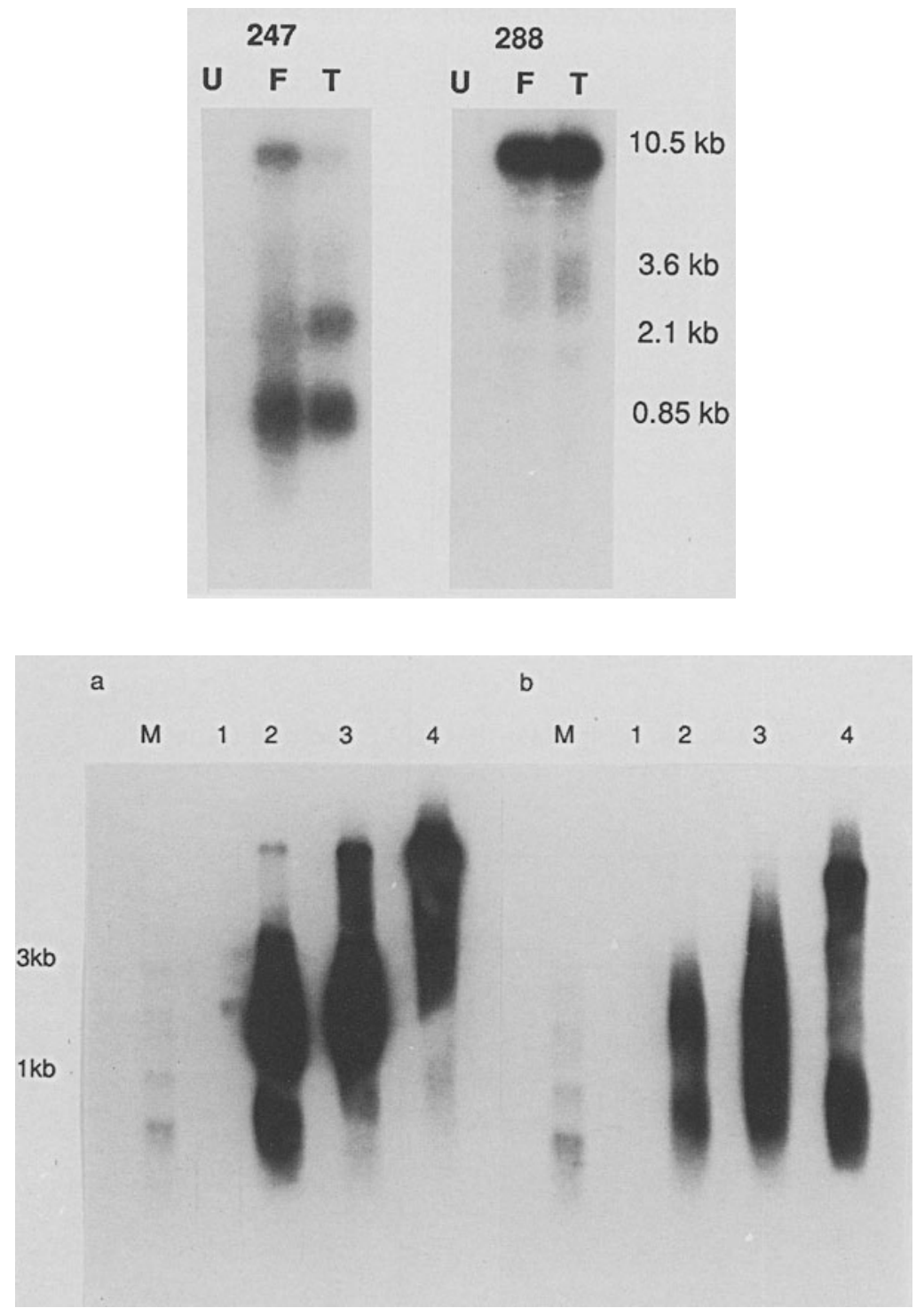

Fig. 5. Analysis of RNA contained in particles isolated from the aqueous phase after Freon extraction of BDV-infected rat brain. Northern blots were analyzed using strandspecific probes. A A Northern blot was sequentially probed with complementary oligonucleotides located in the $24 \mathrm{kD}$ ORF. Oligonucleotide 247 detects sense transcripts; 288 detects anti-sense transcripts. $U 10 \mu \mathrm{g}$ RNA from uninfected rat brain; $F$ $10 \mu \mathrm{g}$ RNA prepared after Freon-extraction of BDV-infected rat brain; $T 10 \mu \mathrm{g}$ total RNA from BDV-infected rat brain. B Northern analysis of Freon extracted rat brain homogenate treated with RNase A prior to preparation of RNA. Rat brain homogenate was extracted with Freon; aliquots were used to prepare RNA directly or they were treated with RNase A at a concentration of $20 \mu \mathrm{g} / \mathrm{ml}$ or $40 \mu \mathrm{g} / \mathrm{ml}$ for $2 \mathrm{~h}$ at room temperature prior to preparation of RNA. Panels $\mathbf{a}$ and $\mathbf{b}$ are transfers from duplicate gels. a was hybridized with a sense RNA probe, $\mathbf{b}$ with an antisense RNA probe. 1 $10 \mu \mathrm{g}$ RNA from uninfected rat brain; 2 RNA from Freon-extracted BDV rat brain treated with $40 \mu \mathrm{g} / \mathrm{ml}$ RNase A prior to RNA preparation ( $25 \mu \mathrm{g}$ RNA); 3 RNA from Freon-extracted BDV rat brain treated with $20 \mu \mathrm{g} / \mathrm{ml}$ RNase A prior to RNA preparation $(25 \mu \mathrm{g}$ RNA); 4 RNA prepared directly from Freon-extracted BDV rat brain 


\section{Analysis of genomic RNA}

Because the original observations of a nested set of $3^{\prime}$ coterminal mRNAs (based on probes derived from the $24 \mathrm{kD}$ ORF) appeared similar to the organization of coronavirus mRNAs, a working hypothesis has been that the genomic RNA is the positive stranded $10.5 \mathrm{~kb}$ species. This has been complicated by the fact that in infected cells the negative strand $10 \mathrm{~kb}$ RNA species is present at much higher levels. In order to address this issue directly, we have conducted experiments to isolate infectious particles from either lysates of infected tissue culture cells or from homogenates of BDV-infected rat brain using a Freon extraction protocol [20]. RNA prepared from these extracts contained BDV-specific RNA of varying sizes and polarities, although it did appear to be enriched for the $10.5 \mathrm{~kb}$ positive strand species (Fig. 5A). However, it was not clear that all these species were within the particles or whether they were nonspecifically copurified with the particles. We then treated a Freon extract from BDV-infected rat brain with RNase A prior to preparing RNA, using the guanidinium isothiocyanate method of RNA isolation [30] to immediately inactivate the RNase. Strand-specific riboprobes were then hybridized to duplicate Northern blots of the RNA. Although this treatment did not remove all small BDV species, it did clearly show that the only $10 \mathrm{~kb}$ species detected after RNase treatment was a negative strand species (Fig. 5B). Because infectious particles are present in the Freon extracted material and the only RNase-resistant genomic sized species detectable is of negative orientation, it seems likely that BDV is a negative strand RNA virus [20].

Although these data strongly suggest that BDV is a negative-strand virus, its classification remains unclear. No other negative-strand RNA viruses are known to have a nested mRNA organization. Also, our clones suggest that the ORFs encoding the probable structural proteins are located at the $3^{\prime}$ end of the positive-strand RNA. Such an organization has not been described for negative-stranded RNA viruses. Further characterization of BDV depends on the isolation of cDNAs encoding additional BDV proteins. Isolation of a clone encoding the polymerase gene(s) may allow its classification because the polymerases are highly conserved between related viruses.

\section{References}

1. Heinig H (1969) Die Borna'sche Krankheit der Pferde und Schafe. In: Roehrer H (ed) Handbuch der Virusinfektionen bei Tieren, vol 4. VEB Fischer, Jena, pp 83-148

2. Zwick W, Seifried O, Witte J (1927) Experimentelle Untersuchungen ueber die seuchenhafte Gehirn- und Rueckenmarks-entzuendung der Pferde (Bornasche Krankheit). Z Infektionskrkh 30: 42-136 
3. Bode L, Riegel S, Ludwig H, Amsterdam J, Lange W, Koprowski H (1988) Borna disease virus specific antibodies in partients with HIV infection and with mental disorders. Lancet 2: 689

4. Rott R, Herzog S, Fleischer B, Winokur A, Amsterdam J, Dyson W (1985) Detection of serum antibodies to Borna disease virus in patients with psychiatric disorders. Science 228: 755-756

5. Carbone KM, Duchala CS, Griffin JW, Kincaid AL, Narayan O (1987) Pathogenesis of Borna disease in rats: evidence that intra-axonal spread is the major route for virus dissemination and the determinant for disease incubation. J Virol 61: 3431-3440

6. Morales JA, Herzog S, Kompter C, Frese K, Rott R (1988) Axonal transpot of Borna disease virus along olfactory pathways in spontaneously and experimentally infected rats. Med Microbiol Immunol 177: 51-68

7. Shankar V, Kao M, Hamir AN, Sheng H, Koprowski H, Dietschold B (1992) Kinetics of virus spread and changes in levels of several cytokine mRNAs in the brain after intranasal infection of rats with Borna disease virus. J Virol 66: 992-998

8. Dittrich W, Bode L, Ludwig H, Kao M, Schneider K (1989) Learning deficiencies in Borna disease virus-infected but clinically healthy rats. Biol Psychol 26: 818-828

9. Narayan O, Herzog S, Frese K, Scheefers H, Rott R (1983) Behavioral disease in rats caused by immunopathological responses to persistent Borna virus in the brain. Science 220: 1401-1403

10. Narayan O, Herzog S, Frese K, Scheefers H, Rott R (1983) Pathogenesis of Borna disease in rats: immune-mediated ophthalmoencephalopathy causing blindness and behavioral abnormalities. J Infect Dis 148: 305-315

11. Stitz L, Soeder D, Deschl U, Frese K, Rott R (1989) Inhibition of immunemediated meningoencephalitis in persistently Borna virus-infected rats by cyclosporine A. J Immunol 143: 4250-4256

12. Herzog S, Wonigeit K, Frese K, Hedrich HJ, Rott R (1985) Effect of Borna disease virus infection on athymic rats. J Gen Virol 66: 503-508

13. Richt JA, Stitz L, Wekerle H, Rott R (1989) Borna disease, a progressive meningoencephalomyelitis as a model for $\mathrm{CD} 4+\mathrm{T}$ cell-mediated immunopathology in the brain. J Exp Med 170: 1045-1050

14. Carbone KM, Trapp BD, Griffin JW, Duchala CS, Narayan O (1989) Astrocytes and Schwann cells are virus-host cells in the nervous system of rats with Borna disease. J Neuropathol Exp Neurol 48: 631-644

15. Buchmeier MJ, Welsh RM, Dutko FJ, Oldstone MBA (1980) The virology and immunobiology of LCM virus infection. Adv Immunol 30: 275-331

16. Ahmed R (1988) Curing of a congenitally acquired chronic virus infection: Acquisition of T-cell competence by a previously "tolerant" host. In: Lopez C (ed) Immunobiology and pathogenesis of persistent virus infections. ASV Publ., Washington, pp 159-167

17. Elford WG, Galloway IA (1935) Filtration of the virus of Borna disease through graded collodion membranes. Br J Exp Pathol 14: 196-205

18. Danner K, Mayr A (1979) In vitro studies on Borna virus. II. Properties of the virus. Arch Virol 61: 261-271

19. Pauli G, Ludwig H (1985) Increase of virus yields and releases of Borna disease virus from persistently infected cells. Virus Res 2: 29-33

20. Richt JA, Clements JE, Herzog S, Pyper J, Wahn K, Becht H (1993) Analysis of virus-specific RNA species in Freon-113 preparations of the Borna disease virus. Med Microbiol Immunol (in press) 
21. Haas B, Becht H, Rott R (1986) Purification and properties of an intranuclear virus-specific antigen from tissues infected with Borna disease virus. J Gen Virol 67: $235-241$

22. Schaedler R, Diringer H, Ludwig H (1985) Isolation and characterization of a 14500 molecular weight protein from brains and tissue cultures persistently infected with Borna disease virus. J Gen Virol 66: 2479-2484

23. Thierer J, Riehle H, Grebenstein O, Binz T, Herzog S, Thiedemann N, Stitz L, Rott R, Lottspeich F, Niemann H (1992) The $24 \mathrm{~K}$ protein of Borna disease virus. J Gen Virol 73: 413-416

24. VandeWoude S, Richt JA, Zink MC, Rott R, Narayan O, Clements JE (1990) A Borna virus cDNA encoding a protein recognized by antibodies in humans with behavioral diseases. Science 250: 1278-1281

25. Richt JA, VandeWoude S, Zink MC, Narayan O, Clements JE (1991) Analysis of Borna disease virus-specific RNAs in infected cells and tissues. J Gen Virol 72: 2251-2255

26. delaTorre JC, Carbone KM, Lipkin WI (1990) Molecular characterization of the Borna disease agent. Virology 179: 853-856

27. Lipkin WI, Travis GH, Carbone KM, Wilson MC (1990) Isolation and characterization of Borna disease agent cDNA clones. Proc Natl Acad Sci USA 87: 4184-4188

28. Pyper JM, Richt JA, Brown L, Rott R, Narayan O, Clements JE (1993) Genomic organization of the structural proteins of Borna disease virus revealed by a cDNA clone encoding the $38 \mathrm{kD}$ protein. Virology 195: 229-238

29. Frohman MA, Dush MK, Martin GR (1988) Rapid production of full-length cDNAs from rare transcripts: Amplification using a single gene-specific oligonucleotide primer. Proc Natl Acad Sci USA 85: 8998-9002

30. Chomczynski P, Sacchi N (1987) Single-step method of RNA isolation by acid guanidinium thiocyanate-phenol-chloroform extraction. Anal Biochem 162: 156-159

Authors' address: Dr. J. M. Pyper, Retrovirus Laboratory, Traylor G-60, Johns Hopkins University School of Medicine, 720 Rutland Avenue, Baltimore, MD 21205, U.S.A. 